\title{
進行期の沖縄型神経原性筋萎縮症における舌および僧帽筋エコ一の検討
}

\author{
吉田 剛 ${ }^{1,2)}$, 中村 洸太 $^{3)}$, 諏訪園 秀吾 ${ }^{1)}$, 末原 雅人 ${ }^{1,4)}$ \\ 1) 国立病院機構沖縄病院神経内科 \\ 2) 沖縄県立中部病院神経内科 \\ 3) 国立病院機構沖縄病院臨床生理検査部門 \\ 4) 藤元総合病院神経内科
}

\section{Ultrasound evaluation of tongue and trapezius muscles in advanced cases of hereditary motor and sensory neuropathy with proximal predominance}

\author{
Takeshi YOSHIDA $^{1,2)}$, Kouta NAKAMURA ${ }^{3)}$, Shugo SUWAZONO ${ }^{1)}$, Masahito SUEHARA ${ }^{1,4)}$ \\ 1) Department of Neurology, National Hospital Organization Okinawa Hospital \\ 2) Department of Neurology, Okinawa Chubu Hospital \\ 3) Department of Physiological Laboratory, National Hospital Organization Okinawa Hospital \\ 4) Department of Neurology, Fujimoto Hospital
}

\begin{abstract}
Purpose: Hereditary motor and sensory neuropathy with proximal predominance (HMSN-P) presents with progressive weakness and atrophy of the proximal limbs and truncal muscles, although the literature has reported marked sparing of the bulbar muscles, distinguishing this pathology from amyotrophic lateral sclerosis (ALS). We sought to clarify whether involvement of the bulbar muscles is present in advanced cases of HMSN-P. Method: We conducted thorough clinical electrophysiological and ultrasonographic examinations in four patients with advanced HMSN-P. We evaluated the presence of fasciculation of the tongue on ultrasonography and fibrillation/positive sharp waves on needle electromyography.

Result: Mean age and disease duration were 69 years and 29 years, respectively. All patients showed near-complete paralysis of all four extremities. Three patients required mechanical ventilation. All four patients revealed tongue atrophy. Although none showed fasciculation of the tongue on visual examination or needle electromyography, ultrasonography detected fasciculation in two patients. Conversely, the two patients without fasciculation showed signs of active denervation on needle electromyography.

Conclusion: This study found evidence of cranial nerve involvement in patients with advanced HMSN-P, but the extent of involvement was much milder than that in ALS. In our patient series, the rate of detecting denervation of the lingual muscles improved with complementary use of both electromyography and ultrasonography.
\end{abstract}

Keywords: hereditary motor sensory neuropathy with proximal predominance, fasciculation, amyotrophic lateral sclerosis

(Received November 12, 2015; Accepted November 17, 2015)

\section{はじめに}

沖縄型神経原性筋萎縮症（hereditary motor and sensory neuropathy with proximal dominant involvement; HMSN-P) は, 1997 年 Takashima らにより沖縄の 8 家 系 23 症例が報告され ${ }^{1)}$, 本邦では沖縄県および滋賀県 において発症がみられる。2012 年, TRK-fused gene (TFG) のミスセンス変異 p.Pro285Leu が沖縄症例およ
び滋賀症例において認められたことが報告された ${ }^{2)}$. TFG は小胞体から Golgi 体を通じて細胞内外への小胞 輸送に関与しており ${ }^{3}$ ，筋萎縮性側索硬化症（amyotrophic lateral sclerosis; ALS）症例においても変異が報告

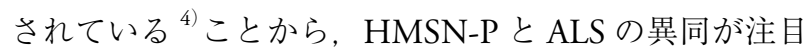
されている。臨床像は 40 歳代から始まる四肢および体 幹筋の緩徐進行性の筋萎縮を呈するが, 既報では障害部 位の明らかな連続性の進展は示さず, さらに脳神経領域 
Table 1 Clinical characteristics

\begin{tabular}{lcccccccccc}
\hline & Age & Sex & $\begin{array}{c}\text { Duration } \\
\text { (y) }\end{array}$ & $\begin{array}{c}\text { Tracheostomy } \\
\text { (y) }\end{array}$ & Dysphagia & Gastrostomy & $\begin{array}{c}\text { EOM } \\
\text { dysfunction }\end{array}$ & $\begin{array}{c}\text { Facial } \\
\text { paresis }\end{array}$ & $\begin{array}{c}\text { Tongue } \\
\text { trophy }\end{array}$ & $\begin{array}{c}\text { Tongue } \\
\text { Fas }\end{array}$ \\
\hline Case 1 & 78 & F & 35 & 5 & - & - & - & - & Slight & - \\
Case 2 & 61 & F & 21 & 8 & - & - & - & - & Slight & - \\
Case 3 & 73 & F & 33 & 3 & - & + & - & + & Mild & - \\
Case 4 & 62 & M & 26 & 8 & - & Due & - & - & Slight & - \\
\hline
\end{tabular}

Abbreviation. Due: scheduled to do, EOM; extraocular muscle, F; female, Fas; fasciculation, M; male, y; years

Table 2 Manual muscle testing (MRC scale, right/left)

\begin{tabular}{ccccccc}
\hline & Trapezius & SCM & UE, proxymal & UE, distal & LE, proxymal & LE, distal \\
\hline Case 1 & $2 / 3$ & $2 / 2$ & $0 / 0$ & $1 / 0$ & $0 / 0$ & $2 / 0$ \\
Case 2 & $4 / 4$ & $4 / 4$ & $1 / 1$ & $0 / 0$ & $0 / 0$ & $1 / 1$ \\
Case 3 & $0 / 0$ & $2 / 2$ & $0 / 0$ & $0 / 0$ & $0 / 0$ & $0 / 0$ \\
Case 4 & $0 / 0$ & $0 / 0$ & $0 / 0$ & $0 / 0$ & $0 / 0$ & $0 / 0$ \\
\hline
\end{tabular}

Abbreviation. LE; lower extremity, SCM; sternocleidomastoid, UE; upper extremity

Table 3 Electromyography and ultrasound

\begin{tabular}{lcccccc}
\hline & Trapezius & Trapezius & Tongue & Tongue & US-trapezius & US-tongue \\
Fib-P/PSW & Fas-P & Fib-P/PSW & Fas-P & Fasciculation & Fasciculation \\
\hline Case 1 & - & - & \pm & - & - & + \\
Case 2 & + & - & - & - & - & + \\
Case 3 & \pm & - & + & - & - & - \\
Case 4 & - & - & $2+$ & - & - & - \\
\hline
\end{tabular}

Abbreviation. Fib-P; fibrillation potential, PSW; positive sharp wave, Fas-P; fasciculation potential

の筋は比較的保たれると報告されている ${ }^{5)}$ 。この臨床像 はALSのそれとは大きく異なっており，両者の病態の 関連を考察するうえで重要であると考える。今回, 我々 は四肢の機能が廃絶している進行期の HMSN-Pにおい て，脳神経支配筋が保たれているどうかを検討し，本症 と ALSの進展様式の違いを明らかにしようと試みた。

\section{方法}

当院筋ジス病棟に長期療養入院中の進行期の HMSN$\mathrm{P}$ 患者 4 症例を対象として, 罹病期間, 気管切開の有無, 嚥下障害（球麻痺）の有無といった臨床情報の収集，診 察による筋力の評価 (Medical Research Council (MRC) scale) とともに電気生理検査 (神経伝導検査, 針筋電図), 舌・僧帽筋のエコー検査を行った。エコー検査において は同一の機器（東芝 APLIO500 TUS-A500）を用い, プ ローブは頸動脈用のものを用いて検査を行った．検査法 については Misawa らの論文 ${ }^{6)}$ を参考にし，主に線維束 攣縮の有無を調べた。

\section{結果}

Table 1 に患者の臨床的特徵を, Table 2 に徒手筋力検 査の結果を示す。平均年齢は 69 歳, 平均罹病期間は 29 年で，四肢の機能は廃絶し，全例が気管切開を受けてい た（ただし，症例 2 については現在のところ人工呼吸 管理を受けていない). 4 例中 3 例は経口摂取を行って いたが，2 例は臨床的に嚥下障害が認められ，1例は胃
瘻増設を予定されていた。顔面麻痺は 1 例に軽度認め られるのみであった。舌萎縮は全例で認めたが, 症例 3 を除けばその程度はごく軽度であった，全例で舌の運動 は保たれ，舌の線維束攣縮は観察されなかった。僧帽筋 および胸鎖乳突筋の筋力は 4 例中 3 例で部分的に残存 していた．眼球運動は全例で正常であった，以上より， 臨床的な評価からは障害が一部の脳神経領域に及んでい るものの，舌においては障害の有無を判断することが困 難であった。

Table 3 にエコー検査および針筋電図検査の結果を示 す。針筋電図上では舌の線維束攣縮電位を認めた症例は なかったが，エコーでは 2 例（症例 1, 症例 2）で線維 束攣縮を検出可能であった。一方，針筋電図では 4 例 中 2 例で線維攣縮電位を検出した（症例 3, 症例 4). その結果，エコーと針筋電図と組み合わせることで，す べての症例において脱神経所見を検出することが可能と なり，舌の障害が存在することを確認できた.

\section{考察}

HMSN-P の進行例を対象とした今回の検討では，針 筋電図検査と舌の超音波検査の結果は相補的なものとな り，両者を同時に行うことにより異常の検出率が上昇す る可能性が示唆された。 また，本症の進行例では舌を含 む脳神経領域の筋の障害を生じるが, その程度はALS と比較して明らかに軽度であり, 本症の重要な臨床的特 徵であることが確認された。 
Table 4 Difference in disease progression and other characteristics between ALS and HMSN-P ${ }^{15) 77}$

\begin{tabular}{ccc}
\hline & ALS & HMSN-P \\
\hline Onset (y) & $30-80$ & $30-40$ \\
Genetics & Familial cases in 10\% & AD TFG mutation \\
Interval between onset and respiratory failure & Few cases with TFG mutaion & 20-30 years \\
Prognosis & $0-60$ months & $30-40$ years \\
Initial symptom & 49 months & Trunk and proximal extremities \\
Continuous progression & UE weakness 33\% & Diffuse, and proximal dominant \\
Bulbar palsy & LE weakness 35\% & \pm \\
DTRs & Bulbar palsy 21\% & Decreased-diminished \\
Sensory disturbance & Inevitable in advanced cases & + \\
Dementia & Increased & - \\
\hline
\end{tabular}

Abbreviation. AD; autosomal dominant, DTRs; deep tendon reflexes, LE; lower extremity, UE; uper extremity, y; years

Misawa らは 81 例の ALS 患者をプロスペクティブに 針筋電図およびエコーを用いて検討した ${ }^{6)}$ 。舌の針筋電 図は一例も線維束攣縮電位を検出できなかったが，工 コーは $60 \%$ の患者で検出可能であった。エコーによる 線維束攣縮電位を Awaji criteriaに加えることで definite ALS の割合が $31 \%$ か 53\%まで $22 \%$ 増加し，そのう ち $10 \%$ は舌の線維束攣縮電位を検出することによるも のであった。我々の症例においても，針筋電図にエコー 検査を加えることで脱神経所見の検出が可能な症例が 2 例から 4 例全例に増加した。このことは，舌の評価に おいて 2 つ検査が相補的な関係であることを示唆し ている.

ALS と HMSN-P の相違点を Table 4 に示す. ALS は 通常，一側の上肢あるいは下肢，あるいは球麻痺で初発 し，連続性の進展を示す。一方，HMSN-P は症状に明 らかな左右差は示さない代わりに近位優位の分布を示 し，進展様式は連続性でなく四肢・体幹の脱力が同時に 進行する，ALSでは通常上位ニューロン障害により反 射立進を示すが，HMSN-Pでは腱反射は早期より低下 または消失する。ALSの一部は認知症を合併するが, HMSN-P と認知症の関連についての報告は見られない. 以上より，ALS は連続性の進展を示し，進行とともに 広範な脳および脳幹の障害を呈するのに対し, HMSN$\mathrm{P}$ では連続性の進展は見られず，脳幹よりも上位の障害 は限定的であることがわかる。

HMSN-P と ALS 以外にも TFG 遺伝子変異と関連し て複数の神経疾患が報告されている，変異部位による臨 床像の相違の背景にある病態メカニズムの詳細は不明で ある。徳島大学神経内科より 2 例の TFG 遺伝子変異を 有するALS 症例が報告されており，孤発性 ALS に合致 する臨床像を示した ${ }^{4)}$. 痤性対麻痺, Charcot-Marie-
Tooth 病，および運動ニューロン病において，TFGを はじめとする多数の小胞体輸送に関与する遺伝子異常が 報告されている。TFGの研究がさらに進むことにより， 遺伝子変異から運動ニューロン死, そして臨床症状の発 現に至るメカニズムが明らかになると期待される.

\section{結語}

進行期の HMSN-P では，舌を含む脳神経筋が障害さ れることが明らかとなった. 舌の障害の有無の確認には, 針筋電図と超音波検査が相補的な役割を果たした。国内 外で TFG 遺伝子に関する研究が行われているが，各症 例の臨床像の正確な評価には舌の超音波検査が有効であ ると考える。今後 HMSN-P が臨床面と分子生物学的な 両面からさらに解明が進むことが期待され，その中で超 音波検査は今後も重要な検査として活用されることが望 まれる。

\section{○文献}

1) Takashima $H$, Nakagawa $M$, Nakahara $K$, et al.: A new type of hereditary motor and sensory neuropathy linked to chromosome 3. Ann Neurol 1997; 41: 771-780.

2) Ishiura $\mathrm{H}$, Sako $\mathrm{W}$, Yoshida $\mathrm{M}$, et al.: The TRK-fused gene is mutated in hereditary motor and sensory neuropathy with proximal dominant involvement. Am J Hum Genet 2012; 91: 320-329.

3) Witte K, Schuh AL, Hegermann J, et al.: TFG-1 function in protein secretion and oncogenesis. Nat Cell Biol 2011; 13: 550558.

4) 瓦井俊孝, 森垣竜馬, 藤田浩司, 他 : 近位筋優位遺伝性運動 感覚ニューロパチーの分子病態機序. 神経内科 2013; 79: 751-756.

5）末原雅人：2. 神経ネットワークシリーズ 沖縄型家族性神経 原性筋萎縮症. 医療 2001; 55: 101-103.

6) Misawa S, Noto Y, Shibuya K, et al.: Ultrasonographic detection of fasciculations markedly increases diagnostic sensitivity of ALS. Neurology 2011; 77: 1532-1537.

7）辻省次, 他：すべてがわかるALS ·運動ニューロン疾患, 東 京：中山書店, 2013, p14-30. 